\title{
Perbandingan evaluasi fisik dari formulasi sediaan sabun padat ekstrak etanol 96\% daun bawang dengan memanfaatkan minyak jelantah dan minyak sawit kemasan
}

\author{
Elfia Neswita $^{1}$ \\ ${ }^{1}$ Program Studi Farmasi Klinis Universitas Prima Indonesia
}

\begin{abstract}
ABSTRAK
Sabun merupakan hasil reaksi saponifikasi/penyabunan dari suatu basa $(\mathrm{NaOH} / \mathrm{KOH})$ dengan asam lemak. Minyak minyak jelantah adalah minyak limbah yang berasal dari jenis-jenis minyak goreng. Tujuan penelitian ini adalah untuk mengetahui perbandingan evaluasi fisik formulasi sediaan sabun padat ekstrak daun bawang dengan minyak jelantah dan formulasi sediaan sabun padat ekstrak daun bawang dengan minyak goreng sawit kemasan. Metode penelitian yang digunakan adalah esperimental, pembuatan ekstrak daun bawang menggunakan metode maserasi dengan pelarut etanol $96 \%$ kemudian dipekatkan dengan rotary evaporator. Evaluasi sediaan menggunakan uji organoleptis, homogenitas, $\mathrm{pH}$, dan iritasi. Hasil penelitian menunjukkan bahwa sediaan berwarna putih kekuningan sampai hijau tua, bertekstur padat dan beraroma mint, homogen, pH yang dihasilkan sediaan sabun ini adalah kisaran 10,1 hingga 10,5. Sabun yang dihasilkan tidak terjadi iritasi, tidak mengalami perubahan bentuk, warna dan bau. Berdasarkan evaluasi uji organoleptis, uji homogenitas, uji pHuji iritasi, dan uji iritasi sabun padat ektstrak daun bawang dengan minyak jelantah sama baiknya dengan formulasi sabun padat ekstrak daun bawang dengan minyak goreng sawit dan memenuhi persyaratan sabun padat yang baik. Disarankan pada penelitian selanjutnya untuk meneliti uji stabilitas busa, uji kadar air, uji hedonic, uji cycling, pH cycling, uji efektifitas anti bakteri sediaan sabun padat ekstrak daun bawang (Allium fistulosum) terhadap penguijian antibakteri.
\end{abstract}

Kata kunci: sabun padat, daun bawang, minyak jelantah, minyak goreng kemasan

Soap is the results of a saponification of a base ( $\mathrm{NaOH} / \mathrm{KOH})$ with fatty acids. Used cooking oil is a waste oil derived from various types of cooking oil. The purpose of this study was to compare the physical evaluation of leek extract solid soap formulations with used cooking oil and leek exytact solid soap formulations with packaged palm cooking oil. The research method used is experimental, the manufacture of leek extract using the maceration method with $96 \%$ ethanol solvent then concentrated with a rotary evaporator. Evaluation of the preparation used organoleptic, hmogenity, $\mathrm{pH}$, and irritation tests. The results shower that the preparation was yellowish white to dark green, solid textured and minty scented, homogeneous, the $\mathrm{pH}$ of this soap preparation was in the range of 10,1 to 10,5. The resulting soap does not cause irritation, does not change shape, color and odor. Based on the evaluation of organoleptic test, homogeneity test, $\mathrm{pH}$ test, and irritation test, leek extract solid soap with used cooking oil was as good as leek extract solid soap formulation with palm cooking oil and met the requirements for a good solid soap. It is recommended for further research to examine the foam stability test, water content test, hedonic test, cycling test, $\mathrm{pH}$ cycling, and test the antibacterial efeectiveness of leek (Allium fistulosum)extract of solid soap for antibacterial testing.

Keywords: Solid soap, leek, cooking oil, packaged cooking oil

*Alamat korespondensi: elfianeswita@gmail.com DOI: $10.34012 /$ jpms.v3i2.2035

\section{PENDAHULUAN}

Setiap rumah tangga menghasilkan salah satu limbah yaitu minyak jelantah. Secara umum yang disebut limbah adalah bahan sisa yang dihasilkan dari suatu kegiatan dan proses produksi, baik pada skala rumah tangga, industri, pertambangan, dan sebagainya. Apabila limbah minyak jelantah dari usaha 
kuliner maupun dari rumah tangga langsung dibuang ke lingkungan, maka akan menjadikan lingkungan kotor dan bahan pencemar bagi air maupun tanah. Minyak jelantah dapat dimanfaatkan kembali, salah satunya dengan menjadikan produk berbasis minyak seperti sabun cair maupun sabun padat yang bernilai ekonomis. ${ }^{1}$

Selain menghasilkan limbah, setiap rumah tangga juga membutuhkan sabun untuk kebutuhan sehari-hari yang cukup tinggi jumlahnya. Sabun merupakan hasil reaksi saponifikasi/penyabunan dari suatu basa $(\mathrm{NaOH} / \mathrm{KOH})$ dengan asam lemak. Sabun biasanya dikenal dalam dua wujud, yaitu sabun cair dan sabun padat. Perbedaan utama dari kedua sabun tersebut adalah alkali yang digunakan. Sabun padat menggunakan $\mathrm{NaOH}$, sedangkan sabun cair menggunakan $\mathrm{KOH} .{ }^{2}$ Menurut Standar Nasional Indonesia (SNI) tahun 1994, sabun mandi didefinisikan sebagai senyawa natrium dengan asam lemak yang digunakan sebagai pembersih tubuh, berbentuk padat, berbusa, dengan atau penambahan lain serta tidak menyebabkan iritasi pada kulit. Sabun padat atau batang sangat akrab dengan kehidupan seharihari. Keunggulan sabun padat yaitu lebih ekonomis dan memiliki kestabilan fisik yang lebih baik dibandingkan dengan sabun cair. Produk sabun berbasis alam masih sangat jarang ditemui di pasaran, kebanyakan masih mengandung bahan kimia ataupun zat-zat tambahan yang dapat mengiritasi kulit seperti Sodium Lauril Sulfat (SLS) dan Triclosan.Triclosan adalah obat antiseptik yang digunakan untuk melawan bakteri dan jamur. ${ }^{3}$

Kebersihan lingkungan mempunyai arti sebuah keadaan bebas dari kotoran, termasuk diantaranya, debu, sampah, dan bau. Kebersihan adalah praktek menjaga diri sendiri dan lingkungan seseorang besar untuk mencegah penyakit yang meliputi kebersihan rambut, kulit, kuku, tangan, kaki, dan berpakaian. Kebersihan kulit meliputi pembersihan kulit dan juga menjaga kesehatan kulit. Kebersihan adalah praktek menjaga diri sendiri dan lingkungan seseorang besar untuk mencegah penyakit yang meliputi kebersihan rambut, kulit, kuku, tangan, kaki, dan berpakaian. Kebersihan kulit meliputi pembersihan kulit dan juga menjaga kesehatan kulit. ${ }^{4}$

Daun bawang secara turun temurun digunakan sebagai obat batuk, infeksi dan sebagian besar digunakan sebagai bumbu masakan. Namun belum ada penelitian yang menggunakan ekstrak daun bawang sebagai sabun. ${ }^{5}$ Berdasarkan uraian di atas maka penelitian tertarik untuk membuat sabun padat ekstrak daun bawang dengan memanfaatkan minyak jelantah dan membandingkan evaluasi fisik dengan sabun yang dibuat dari minyak sawit kemasan.

\section{METODE}

Desain Studi

Penelitian ini bersifat penelitian eksperimental. Tempat penelitian adalah laboratorium Formulasi Program Studi S-1 Farmasi Institut Kesehatan Helvetia periode November 2019 hingga Januari 2020. Penelitian ini dilakukan selama 3 bulan.

\section{Sampel Penelitian}

Sampel penelitian ini adalah ekstrak daun bawang yang diperoleh dari Berastagi. sampel yang digunakan dalam penelitian yang digunakan dalam penelitian ini adalah ekstrak daun bawang yang terdiri dari variasi konsentrasi yang berbeda-beda 0,25\%, 0,5\% dan 0,75\%.

\section{Alat dan Bahan}

Alat yang digunakan: lumpang dan stamper, beaker glass, penangas air, rotary evaporator, batang pengaduk, neraca analitik, cawan porselen, cawan penguap, pipet tetes, spatula, tabung reaksi, kertas saring, corong, gelas ukur, blender, cetakan sabun, kemasan sabun dan skin analyzer. Bahan yang 
digunakan: daun bawang, etanol 96\%, aquadest, minyak goreg kemasan, minyak jelantah, $\mathrm{NaOH} 30 \%$, asam stearat, asam sitrat, gliserin, gula, parfum mint.

\section{HASIL}

Hasil ekstraksi daun bawang

Daun bawang segar sebanyak $5 \mathrm{~kg}$ dikerinngkan dan didapatkan simplisia kering sebanyak 2.5 kg. Sebanyak 500 gram simplisia kering daun bawang kemudian dimaserasi dengan etanol $96 \%$ dan didapat hasil penyaringan sebanyak 2,2 liter, kemudian ekstrak diuapkan dengan alat rotary evaporator dan hasil ekstrak kental yang didapatkan sebanyak 21.05 gram.

$$
\begin{aligned}
\text { Rendeman } & =\frac{21,05}{500} \times 100 \% \\
= & 4,21 \mathrm{gram}
\end{aligned}
$$

\section{Uji organoleptis}

Pemeriksaan uji organoleptis bertujuan untuk mengetahui tampilan sabun padat berupa bentuk, warna dan aroma yang dilakukan secara menggunakan panca indra, selama penyimpanan 2 minggu. Hasil uji organoleptis sabun padat A dan sabun padat B dapat dilihat padat tabel di bawah ini.

Tabel 1. Hasil pengujian organoleptis sabun padat A (sabun padat dari minyak jelantah)

$\begin{array}{ccccc}\text { Minggu } & \text { Formula } & \text { Warna } & \begin{array}{r}\text { Parameter } \\ \text { Aroma }\end{array} & \text { Tekstur } \\ \text { Ke-0 } & \text { F0 } & \text { Putih } & \text { Mint } & \text { Lunak } \\ \text { Ke-1 } & \text { F0 } & \text { Putih } & \text { Mint } & \text { Padat } \\ \text { Ke-2 } & \text { F0 } & \text { Putih } & \text { Mint } & \text { Padat } \\ \text { Ke-0 } & \text { F1 } & \text { Hijau kekuningan } & \text { Mint } & \text { Lunak } \\ \text { Ke-1 } & \text { F1 } & \text { Hijau kekuningan } & \text { Mint } & \text { Padat } \\ \text { Ke-2 } & \text { F1 } & \text { Hijau kekuningan } & \text { Mint } & \text { Padat } \\ \text { Ke- } 0 & \text { F2 } & \text { Hijau muda } & \text { Mint } & \text { Lunak } \\ \text { Ke-1 } & \text { F2 } & \text { Hijau muda } & \text { Mint } & \text { Padat } \\ \text { Ke-2 } & \text { F2 } & \text { Hijau muda } & \text { Mint } & \text { Padat } \\ \text { Ke-0 } & \text { F3 } & \text { Hijau tua } & \text { Mint } & \text { Lunak } \\ \text { Ke-1 } & \text { F3 } & \text { Hijau tua } & \text { Mint } & \text { Padat } \\ \text { Ke-2 } & \text { F3 } & \text { Hijau tua } & \text { Mint } & \text { Padat }\end{array}$

Tabel 2. Hasil pengujian organoleptis sabun padat B (sabun padat dari minyak kemasan)

$\begin{array}{ccccc}\text { Minggu } & \text { Formula } & \text { Warna } & \begin{array}{c}\text { Parameter } \\ \text { Aroma }\end{array} & \text { Tekstur } \\ \text { Ke- } 0 & \text { F0 } & \text { Putih } & \text { Mint } & \text { Lunak } \\ \text { Ke-1 } & \text { F0 } & \text { Putih } & \text { Mint } & \text { Padat } \\ \text { Ke-2 } & \text { F0 } & \text { Putih } & \text { Mint } & \text { Padat } \\ \text { Ke- } 0 & \text { F1 } & \text { Hijau kekuningan } & \text { Mint } & \text { Lunak } \\ \text { Ke- } 1 & \text { F1 } & \text { Hijau kekuningan } & \text { Mint } & \text { Padat } \\ \text { Ke- } 2 & \text { F1 } & \text { Hijau kekuningan } & \text { Mint } & \text { Padat } \\ \text { Ke- } 0 & \text { F2 } & \text { Hijau muda } & \text { Mint } & \text { Lunak } \\ \text { Ke-1 } & \text { F2 } & \text { Hijau muda } & \text { Mint } & \text { Padat } \\ \text { Ke-2 } & \text { F2 } & \text { Hijau muda } & \text { Mint } & \text { Padat } \\ \text { Ke- } 0 & \text { F3 } & \text { Hijau pekat } & \text { Mint } & \text { Lunak } \\ \text { Ke-1 } & \text { F3 } & \text { Hijau pekat } & \text { Mint } & \text { Padat } \\ \text { Ke-2 } & \text { F3 } & \text { Hijau pekat } & \text { Mint } & \text { Padat }\end{array}$

Keterangan: F0 : Blanko

F1 : Formulasi sabun padat ekstrak etanol daun bawang dengan kosentrasi 0,25\%

F2 : Formulasi sabun padat ekstrak etanol daun bawang dengan kosentrasi $0,5 \%$

F3 : Formulasi sabun padat ekstrak etanol daun bawang dengan kosentrasi $0,75 \%$ 
Perbandingan evaluasi fisik dari formulasi sediaan sabun padat...

\section{Uji homogenitas}

Pengujian homogenitas bertujuan untuk mengetahui ada tidaknya partikel kasar atau padatan. Hasil dari pengujian homogenitas sabun padat A dan sabun padat B dapat dilihat pada tabel 3 .

Tabel 3. Hasil uji homogenitas sabun padat A dan B

$\begin{array}{ccc}\text { Formula } & \text { Sabun A } & \text { Sabun B } \\ \text { F0 } & \text { Homogen } & \text { Homogen } \\ \text { F1 } & \text { Homogen } & \text { Homogen } \\ \text { F2 } & \text { Homogen } & \text { Homogen } \\ \text { F3 } & \text { Homogen } & \text { Homogen }\end{array}$

Uji $\mathrm{pH}$

Pengujian pengukuran $\mathrm{pH}$ bertujuan untuk melihat $\mathrm{pH}$ sediaan yang berpengaruh terhadap sifat iritasi pada kulit. Hasil pengujian uji $\mathrm{pH}$ pada sediaan sabun padat A dan sabun padat B dapat dilihat padat tabel 4 dan tabel 5 .

Tabel. 4. Hasil uji pH sediaan sabun padat A (sabun padat dari minyak jelantah)

$\begin{array}{ccccc}\text { Formula } & \text { Pengulangan 1 } & \text { Pengulangan } 2 & \text { Pengulangan } 3 & \begin{array}{c}\mathrm{pH} \\ \text { Rata-rata }\end{array} \\ \text { F0 } & 10,4 & 10,5 & 10,4 & 10,43 \\ \text { F1 } & 10,3 & 10,5 & 10,4 & 10,40 \\ \text { F2 } & 10,2 & 10,3 & 10,2 & 10,23 \\ \text { F3 } & 10,1 & 10,1 & 10,2 & 10,13\end{array}$

Tabel. 5. Hasil uji pH sediaan sabun padat B (sabun padat dari minyak kemasan)

$\begin{array}{ccccc}\text { Formula } & \text { Pengulangan 1 } & \text { Pengulangan 2 } & \text { Pengulangan } 3 & \begin{array}{c}\mathrm{pH} \\ \text { Rata-rata }\end{array} \\ \text { F0 } & 10,3 & 10,2 & 10,2 & 10,23 \\ \text { F1 } & 10,4 & 10,3 & 10,4 & 10,36 \\ \text { F2 } & 10,3 & 10,4 & 10,4 & 10,36 \\ \text { F3 } & 10,2 & 10,2 & 10,1 & 10,16\end{array}$

\section{Uji iritasi}

Berdasarkan uji iritasi terhadap 12 panelis sukarelawan di mana setiap formula sabun padat A dan sabun padat B dioleskan di bagian belakang telinga kemudian ditunggu selama 24 jam dan dilihat perubahan yang terjadi. Hasil dapat dilihat pada tabel di bawah ini.

Tabel 6. Hasil uji iritasi sabun padat A (sabun padat dari minyak jelantah)

\begin{tabular}{|c|c|c|c|c|}
\hline Formula & Pengulangan & Kemerahan pada kulit & Gatal pada kulit & Bengkak pada kulit \\
\hline \multirow{3}{*}{ F0 } & $\mathrm{P} 1$ & - & - & - \\
\hline & $\mathrm{P} 2$ & - & - & - \\
\hline & P3 & - & - & - \\
\hline \multirow{3}{*}{ F1 } & $\mathrm{P} 1$ & - & - & - \\
\hline & $\mathrm{P} 2$ & - & - & - \\
\hline & P3 & - & - & - \\
\hline \multirow{3}{*}{$\mathrm{F} 2$} & $\mathrm{P} 1$ & - & - & - \\
\hline & $\mathrm{P} 2$ & - & - & - \\
\hline & $\mathrm{P} 3$ & - & - & - \\
\hline \multirow{3}{*}{ F3 } & $\mathrm{P} 1$ & - & - & - \\
\hline & $\mathrm{P} 2$ & - & - & - \\
\hline & P3 & - & - & - \\
\hline
\end{tabular}


Tabel 7. Hasil uji iritasi sabun padat B (sabun padat dari minyak kemasan)

\begin{tabular}{|c|c|c|c|c|}
\hline Formula & Pengulangan & Kemerahan pada kulit & Gatal pada kulit & Bengkak pada kulit \\
\hline \multirow{3}{*}{ F0 } & $\mathrm{P} 1$ & - & - & - \\
\hline & $\mathrm{P} 2$ & - & - & - \\
\hline & P3 & - & - & - \\
\hline \multirow{3}{*}{ F1 } & P1 & - & - & - \\
\hline & P2 & - & - & - \\
\hline & P3 & - & - & - \\
\hline \multirow{3}{*}{$\mathrm{F} 2$} & $\mathrm{P} 1$ & - & - & - \\
\hline & $\mathrm{P} 2$ & - & - & - \\
\hline & P3 & - & - & - \\
\hline \multirow{3}{*}{ F3 } & P1 & - & - & - \\
\hline & $\mathrm{P} 2$ & - & - & - \\
\hline & P3 & - & - & - \\
\hline
\end{tabular}

Keterangan : + : Terjadi iritasi - : Tidak terjadi iritasi

\section{PEMBAHASAN}

Hasil maserasi dari 500 gr serbuk simplisia daun bawang dengan pelarut etanol $96 \%$ yang dipekatkan menggunakan rotary evaporator pada temperatur $60^{\circ} \mathrm{C}$ diperoleh ekstrak kental sebanyak 21,05 gr di mana didapatkan ekstrak daun bawang adalah 4,21 gram. Pada ekstraksi ini terjadi karena pelarut yang digunakan pada saat maserasi adalah etanol $96 \%$ yang bersifat polar, sehingga dapat mengekstrak komponen daun bawang yang hanya bersifat polar saja. ${ }^{5}$

Uji organoleptis berupa pengamatan secara indra penglihatan yang meliputi bentuk, warna, dan aroma. Pengujian ini dilakukan selama penyimpanan 2 minggu. Hasil pengamatan yang dilakukan terhadap bentuk sabun padat minyak jelantah dan sabun padat minyak kemasan ekstrak daun bawang pada minggu ke-0 semua formula masih berbentuk lunak. Sedangkan bentuk sabun pada minggu ke-1 dan minggu ke-2 semua sabun sudah mengeras sempurna dan tidak ada mengalami perubahan. Uji terhadap warna sabun padat minyak jelantah dan sabun padat minyak kemasan pada minggu ke-0 semua formula menghasilkan warna sabun yaitu warna putih, putih kekuningan, hijau kekuningan, hijau pekat. Dan pada minggu ke-1 sampai kedua masih berwarna tetap dan tidak mengalami perubahan. Perubahan warna terjadi diakibatkan penambahan bahan ekstrak daun bawang yang berwarna hijau, semakin tinggi kosentrasi sabun padat ekstrak daun bawang maka semakin hijau warna yang dihasilkan. Sedangkan pada pengujian terhadap bau pada minggu ke-0 sampai minggu ke-2 memiliki aroma wangi mint, dan tidak mengalami perubahan.

Uji homogenitas bertujuan untuk melihat ada tidaknya butiran atau partikel-partikel kasar yang terdapat pada sabun. Uji homogenitas Pada sediaan sabun padat minyak jelantah dan sabun padat minyak kemasan semua formula dinyatakan homogen, dikarenakan tidak terdapat partikel-partikel kasar pada objek glass. Dan sabun dinyatakan memenuhi persyaratan homogenitas sabun bila tidak terdapat bagian yang tidak mengumpal atau tidak terdapat butiran-butiran kasar pada permukaan dan bagian dalam sabun. ${ }^{3,10}$.

Nilai $\mathrm{pH}$ merupakan parameter yang sangat penting dalam sediaan sabun padat, karena nila $\mathrm{pH}$ menentukan layak atau tidaknya sabun digunakan untuk sediaan sebagai sabun. $\mathrm{pH}$ yang tinggi maupun rendah dapat menambah daya absorbansi kulit sehingga dapat mengiritasi kulit. Syarat $\mathrm{pH}$ sabun menurut SNI umumnya berkisar antara 9-11. Nilai pH semua formulasi sabun padat minyak jelantah dan sabun minyak kemasan ekstrak daun bawang menghasilkan sabun bersifat basa, dikarenakan $\mathrm{pH}$ dari semua formulasi yang didapat berkisar 10,13\% sampai 10,43\% dan sabun dinyatakan telah memenuhi persyaratan sebagai sabun hal ini sesuai menurut Hernani dkk. (2010) standar nilai $\mathrm{pH}$ untuk sabun yaitu 9-11.,4,6 
Perbandingan evaluasi fisik dari formulasi sediaan sabun padat...

Kandungan karakteristik dan penggunaan sabun padat yang kurang baik dapat menyebabkan reaksi berupa iritasi pada kulit, oleh karena itu dilakukan uji iritasi untuk mengetahui ada atau tidaknya reaksi berupa iritasi tersebut terhadap kulit. Iritasi diamati dengan melihat terjadinya perubahan pada kulit seperti kemerahan, gatal, dan kasar. Berdasarkan hasil uji iritasi pada semua sediaan sabun minyak jelantah dan sabun minyak kemasan ekstrak daun bawang menunjukkan bahwa tidak ada mengakibatkan efek samping berupa kemerahan, gatal, dan pengasaran kulit yang ditimbulkan oleh sediaan. ${ }^{4,7,8}$ Oleh karena itu sediaan sabun padat minyak jelantah dan minyak kemasan ekstrak daun bawang dapat digunakan.

\section{KESIMPULAN}

Dari penelitian yang telah dilakukan dapat diambil kesimpulan bahwa ekstrak daun bawang dapat diformulasikan menjadi sediaan sabun padat. Dari hasil perbandingan evaluasi sabun padat minyak jelantah dan minyak sawit kemasan sama baiknya. Berdasarkan evaluasi uji organoleptis, uji homogenitas, uji $\mathrm{pH}$, uji iritasi, dan uji iritasi sabun padat ektstrak daun bawang dengan minyak jelantah sama baiknya dengan formulasi sabun padat ekstrak daun bawang dengan minyak goreng sawit dan memenuhi persyaratan sabun yang baik.

\section{REFERENSI}

1. Chan A. Formulasi Sediaan Sabun Mandi Padat Dari Ekstrak Buah Apel (Malus domesticus) Sebagai Sabun Kecantikan Kulit. J Ilm Manuntung. 2017;2(1):51-55. doi:10.51352/jim.v2i1.46

2. Gusviputri A, Meliana N, Aylianamawati, Indraswati N. Pembuatan Sabun dengan Lidah Buaya (Aloe vera) sebagai Antiseptik Alami. Widya Tek. 2013;12(1):11-21.

3. Amid A, Ismail NA, Yusof F, Salleh HM. Expression, purification, and characterization of a recombinant stem bromelain from Ananas comosus. Process Biochem. 2011;46(12):2232-2239. doi:10.1016/j.procbio.2011.08.018

4. Aminullah, Suhartani R, Novidahlia N. Penggunaan Bubuk Kulit Pisang Kepok (Musa paradisiaca) Sebagai Adsorben Terhadap Sifat Fisikokimia Minyak Jelantah. J Agroindustri Halal. 2018;4(2):162-171. doi:10.30997/jah.v4i2.1289

5. Wijaya J, Rohanah A, Rindang A. Pengolahan Minyak Jelantah Menjadi Sabun Batang Dengan Ekstrak. J Rekayasa Pangan dan Pertan. 2014;2(4):139-145.

6. Widyasanti A, Farddani CL, Rohdiana D. Pembuatan Sabun Padat Transparan Menggunakan Minyak Kelapa Sawit (Palm oil) Dengan Penambahan Bahan Aktif Ekstrak Teh Putih (Camellia sinensis). Tek Pertan Lampung. 2016;5(3):125-136.

7. Noormindhawati L, Lestari DP. Jurus Ampuh Melawan Penuaan Dini. Jakarta: PT. Elex Media Komputindo; 2013.

8. Muliyawan D, Suriana N. A - Z Tentang Kosmetik. Jakarta: Elex Media Komputindo; 2013. 